\title{
Acceptability Rate of Smoked and Electric Dried Synodontis Veremiculatus in the Niger Delta Region
}

\author{
${ }^{1}$ Nwachi oster and ${ }^{2}$ Uzokiwe uche \\ ${ }^{I}$ Department Of Fisheries And Aquaculture, Delta State University Abraka, Asaba Campus \\ ${ }^{2}$ Department Of Agric Economics And Extension, Delta State University Abraka, Asaba Campus.
}

\begin{abstract}
A comparative study on the texture, flavor, taste, appearance and acceptability of smoked and electric dried Synodontis vermiculatus was carried out at Amukpe Sapale local government of Delta state Nigeria, to determine the best processing and storing methods to be adopted by the fisher folk. The fish was processed for a period of 20 hours during the smoking while the processing time for the electric drying was for a period of 14 hours. A panel of 20 gave the electric dried dried S.vermiculatus the best score while the acceptability rate was given to the smoked fish.
\end{abstract}

\section{Introduction}

Fish is one of the most perishable of all staple food because of spoilage (Eyo, 2001). Spoilage commences immediately after the fish dies and this is enhanced due to high temperature (Omojowo and Inuali, 2006). A report by Eyo, (2006) indicates that $17.5 \%$ of the $40 \%$ intake of protein in the area comes from fish hence the need to develop the production, processing and the preservation of fish at capture in fishing activities and at harvest during culture. Intensification by the use of high technology at capture and even at culture should be followed with ample work on the way to preserve the products and make it available to the consumers who rely on cheap source of protein to meet their protein need (Davies and Davies 2009). In fishing industry, quality control begins the moment a fish is captured or even harvested from a water bearing receptacle (Oluwaniyi and Dosumu, 2009). The manner and way a fish is handled from capture till it is presented to the final consumer could be defined as attribute which makes the fish acceptable, some of the important factors considered by consumers include freshness, the microbial load, pathogenic organism present or absent, palatability, and texture (Abolagba, and Melle 2008).. The market value and demand of a product lies on the quality of product at point of sell. (Olokor and Omojowo, 2009) The Niger delta area of Nigeria is known for her numerous water bodies where fresh water and brackish water with many pelagic and dermal fish stocks with seasonal peaks in occurrence, however due to poor handling, preservation, storage and processing partial or in extreme case complete loss of fish market value occur as result or poor handling at or between the stages of capture, harvest (Aquaculture), processing, transportation and marketing of the product (Eyo, 1996) Among the processing methods used in preserving and prepare fish for sell are smoking with wood and use of electric drier, this work is aimed at examining both type of processing and preservation methods to ascertain the preferred method.

\section{Materials And Methods}

The work was carried out in Amukpe at Sapale local government. Sapale is a coastal town situated on the south fringe of the navigable branch-off of the Ethiope River. A total of forty (40) samples of Synodontis vermiculatus were obtained from the landing site of the local fisher folks in Amukpe. The fishes were degutted by cutting the ventral surface of the fish from vent to the gill opening and removing the visceral, the gutted fish were dipped into a brine solution

\section{Smoking}

A total of randomly selected fish species was placed into the traditional smoking kiln for a total of 20 hours, the fish was closely monitored to prevent burnt and making sure that the heat produced by the kiln was adequate during the smoking period.

\section{Electrical drying}

Domestic kitchen drier was used for the twenty (20) fish species, an alternative source of power was put on stand-by during the period of drying to ensure adequate and well spread drying process, after a period of fourteen (14) hours of constant drying the fish was removed from the drier because further drying would have affect the quality of fish adversely.

Assessments of the quality of the preserved specimen were done by subjective method only. 


\section{Organoleptic Test}

A panel of 20 DELSU staff and University community comprising of 10 males and 10 females were used to evaluate the processed fishes. This panel was randomly selected from the Delta State University (Asaba Campus) community. Their task was to determine the differences in appearance, texture, flavor, taste and overall acceptability of preserved synodontis vermiculatus by using

\section{STATISTICAL ANALYSIS}

To determine the likeness in the consumption of electric dried synodontis vermiculatus and smoked synodontis vermiculatus, a five (5) point likert scale was developed and used in the Analysis. The responses of an item for each variable were multiplied by the weight attached to obtain response scores. The mean response values are as follows:

$$
\begin{aligned}
& \text { Strongly like } \quad=5 \\
& \text { Like }=4 \\
& \text { Undecided }=3 \\
& \text { Dislike } \quad=2 \\
& \text { Strongly dislike }=\mathrm{I} \\
& X=\Sigma x \frac{\mathrm{x}}{\frac{\mathrm{n}}{-}} \\
& \text { Where } X=\text { mean } \\
& \mathrm{Z}=\text { sum of } \\
& \mathrm{X}=\text { nominal value of the response } \\
& \mathrm{F}=\text { frequency of response under each mode } \\
& \mathrm{n}=\text { number of respondents to an item }
\end{aligned}
$$

\section{Determination of Cut-off Point}

The cut-off point was determined by finding the mean of the nominal value assigned to the options

\begin{tabular}{|c|c|c|c|c|c|c|}
\hline Variable & $\begin{array}{c}\text { Strongly like } \\
5\end{array}$ & Like 4 & $\begin{array}{c}\text { Undecided } \\
3\end{array}$ & $\begin{array}{c}\text { Dislike } \\
2\end{array}$ & $\begin{array}{r}\text { Strongly } \\
\text { dislike } 1\end{array}$ & $\begin{array}{r}\text { Mean } \\
x-\end{array}$ \\
\hline Texture & 12 & 8 & 0 & 0 & 0 & 4.60 \\
\hline Flavour & 4 & 15 & 1 & 0 & 0 & 4.15 \\
\hline Acceptability & 8 & 10 & 1 & 1 & 0 & 4.25 \\
\hline Appearance & 14 & 6 & 0 & 0 & 0 & 4.70 \\
\hline Taste & 4 & 15 & 1 & 0 & 0 & 4.15 \\
\hline
\end{tabular}
using the formula:

$$
\begin{aligned}
& X=\Sigma \frac{\mathrm{xf}}{\mathrm{n}} \\
& X=5+4+3+2+1=3.0
\end{aligned}
$$

To make inferential statements, the mean score was compared with the critical mean of 3.00. If the calculated mean is greater than the standard critical value, the hypothesis is rejected; otherwise it is accepted (Mitchell and Agenmonmen, 1984).

\section{Electric - Dried Synodontis Vermiculatus}

\section{Summary Of Findings And Discussion}

Data generated for the study indicate that most of the consumers expressed that they strongly like the various "likeness variables" that were measured. This is as presented in table 1.

Table 1: Assessment of electric-dried S.vermiculatus

A detailed Analysis of the table shows that the appearance of the electric-dried synodontis vermiculatus has the highest mean score for the likeness variables. It has a mean score of 4.70. All other variables are also significant. The mean of all the mean ratings of the variables is 4.37 indicating an overall significance. However, the flavor and the taste of the electric-dried Synodontis vermiculatus are equally liked by consumers. They both have an average mean rating of 4.15.Texture and Acceptability variables on the other hand have mean ratings of 4.60 and 4.25 respectively indicating that they are also among the highly liked variables in electric dried Synodontis vermiculatus. 


\section{Smoked Synodontis Vermiculatus}

An Analysis of the response of consumers on the likeness of smoked Synodontis vermiculatus reveals that four (4) variables are significant, they are acceptability; texture, taste and appearance which have mean ratings of 4.35.4.10, 3.80 and 3.5 respectively.

The Appearance variable is not significant as the mean rating is 2.60 . This implies that consumers do not appreciate the appearance of smoked Synodontis vermiculatus the summary of the ratings are presented in Table 11 below.

\begin{tabular}{|c|c|c|c|c|c|c|}
\hline Variable & $\begin{array}{c}\text { Strongly like } \\
\mathbf{5}\end{array}$ & Like 4 & $\begin{array}{c}\text { Undecided } \\
3 \\
\end{array}$ & $\begin{array}{c}\text { Dislike } \\
2 \\
\end{array}$ & $\begin{array}{l}\text { Strongly } \\
\text { dislike } 1\end{array}$ & $\begin{array}{r}\text { Mean } \\
x-\end{array}$ \\
\hline Texture & 8 & 6 & 6 & 0 & 0 & 4.10 \\
\hline Flavour & 4 & 6 & 6 & 4 & 0 & 3.50 \\
\hline Acceptability & 10 & 7 & 3 & 0 & 0 & 4.35 \\
\hline Appearance & 2 & 4 & 4 & 4 & 6 & 2.60 \\
\hline Taste & 6 & 4 & 10 & 0 & 0 & 3.80 \\
\hline
\end{tabular}

The mean of the mean ratings of the variables is 3.67 and this indicates that the overall likeness of smoked synodontis vermiculatus by the respondent consumers sampled for this study was also significant.

\section{Comparative Analysis of Consumer of Electric Dried and Smoked Synodontis Vermiculatus}

A comparative analysis of the value of the mean ratings likeness variables between the two forms of fish preservation reveals that the electric dried fish is more liked than the smoked fish. This is as presented in table 111.

Table 111: Mean Ratings of Electric dried and Smoked Synodontis Vermiculatus

\begin{tabular}{|c|c|c|}
\hline \multirow[t]{2}{*}{ VARIABLES } & \multicolumn{2}{|c|}{ MEAN RATINGS } \\
\hline & Electric Dried & Smoked \\
\hline Texture & 4.60 & 4.10 \\
\hline Flavour & 4.15 & 3.50 \\
\hline Acceptability & 4.25 & 4.35 \\
\hline Appearance & 4.70 & 2.60 \\
\hline Taste & 4.15 & 3.80 \\
\hline
\end{tabular}

A study of the above table reveals that only the Acceptability variable is liked more in smoked S.vermiculatus that its electric dried counterpart. Other likeness variables such as texture, flavor, appearance and taste are preferred by consumers in the electric dried fish than the smoked type.

\section{Conclusion}

The panelists used in this study were untrained. However, their responses suggest that there are some significant differences between the smoked S.vermiculatus and the electric dried one especially in the texture, flavor and appearance. In fact, the results showed that preference of electric dried synodontis vermiculatus is influenced by the organoleptic characteristics.

Furthermore, the results suggest that electric drying produces a better tastier quality of synodontis vermiculatus than smoking method.

\section{Recommendations}

Based on the results of the study, electric drying produces a more acceptable product However; further research should be carried out to confirm the observation using the two different processing/preservation methods used for this study. Further research is needed to ascertain the effects of smoke on human health and bacteriological test on processed fish which are to be stored for long time.

\section{References}

[1]. Abolagba, O.J and Melle, O.O. (2008). Chemical composition and keeping Qualities of a Scaly fish Tilapia, Oreochromis niloticus smoked with two Energy sources. African Journal of General Agriculture, vol. 4, No. 2.

[2]. Davies, R.M. and Davies, O.A. (2009). Traditional and Improved fish Processing Technologies in Bayelsa state, Nigeria. European Journal of Scientific research, 1SSN 1450-216 x Vol. 26 No. 4, pp. 539-548.

[3]. Eyo, A.A. (1996). Handling fish in Inland waters. NIFFR Extension Guide series No. 9, pp 1 -2.

[4]. Eyo, AA. (2001). Fish Processing Technology in the tropics. University of Iftorin Press. 1 Edition, pp 1-265.

[5]. Eyo, A.A. (2006). Fish Processing Technology in the tropics. University of Illorin Press. $2^{\text {nd }}$ Edition, pp 1-300

[6]. Mitchell, L.H., and Agenmonmen, Al (1984). Marketers Attitudes Towards the marketing concepts in Nigeria Business Operators in the Columbia. Journal of world Business vol. 29 No.3; pp 37-41.

[7]. Oluwaniyi O.O. and Dosumu, O.O. (2009). Preliminary studies on the effect of processing methods on the quality of three commonly consumed marine fishes in Nigeria society for Experimental Biology 21 (1):1-7. 
[8]. Olokor, J.O, Omojowo F.S, Ihuahi J.A, Adelowo E.O, (2007). Handbook of practical fisheries Technology. Remi Thomas press pp 135 .

[9]. Olokor, J.O; Ugoala, C. and lbitoya, A. (2009). Study of fish weight loss in solar Dryer Across Different Agro-Ecological Zones of Nigeria. Nature proceedings: doi:10.1038/npre.

[10]. Omojowo, F.S. and Ihuali, J.A. (2006). Microbiological Quality and safety of smoked fish from Kainji lake Area. In African Scientist, Vol. 7, No. 4. 